\title{
The Principle of Effective and Efficient Restructuring and the Future of the Nigerian Nation: The Role of Social Science Education
}

\author{
Chuks Justus Iwegbu \& Emmanuel C. Uwaifo \\ http://dx.doi./org/10.4314/ujah.v21i3.3
}

\begin{abstract}
This study on 'The Principle of Effective and Efficient Restructuring and the Future of the Nigerian Nation: The Role of Social Science Education' examines critically the meaning of Restructuring and effective restructuring defining restructuring as a concept which connotes the act of re-organizing, re-arranging, re-planning all the existing institutions and structures in the society while effective and efficient restructuring is one which encapsulate Economic, Political, Social, Cultural Educational, Health structures and institutions of any nation for a possible new and better result for renewed development of man and his environment. The various types of restructuring in our society were outlined and briefly explained with particular emphasis and restricted attention given to Economic Restructuring. The role of Social Science Education in achieving all round restructuring projects for all round national development and sustained unity is holistically discussed. The issue of entrepreneurship is also highlighted as a positive step towards attaining Economic Restructuring. The paper concludes by asserting that functional and effective Entrepreneurship Education in a nation is a panacea for a sustained restructured economy and recommendations on how to better the process of all inclusive Economic Restructuring was proffered.
\end{abstract}

Keywords: Restructuring, Economic Restructuring, Entrepreneurship, Entrepreneurship Education 


\section{Introduction}

The concept of restructuring though is as old as the modern day diction, the concept has lately taken over debates and discussions in the political, economic and the academic space of Nigeria. To say that the concept of restructuring has become a household expression and discourse in Nigeria since the second year into the government of the present administration is to state the obvious. The market men and women, the Politicians, the Pastors, the Okada riders, the taxi drivers alike itch to hear more on restructuring even when they do not understand the meaning and process of the concept whenever the word "Restructuring" is mentioned. The anxiousness, the anger, the enthusiasm and the interest people both the lettered and the otherwise express openly may not really be divorced from the perceived failure of governance in Nigeria today. People are today becoming too agitated partly because of what they see to be lopsidedness in appointments, promotions, developmental efforts by the government of today with very conspicuous references emanating daily and the people mostly the perceived deprived, believe that only the restructuring of both the economic and political structures and institutions in Nigeria can permanently change the "Status Quo Entre".

\section{Conceptual Clarification of Basic Concepts The Concept and Philosophy of the Social Sciences}

The philosophy of the Social Sciences is the study of the Logic, Methods, and foundation of the Social Sciences (Comte, in Mordi \& Jike, 2005). Social sciences according to Mordi \& Jike (2005) are important category of academic disciplines concerned with the basic understanding of human society and the relationships among individuals within a society. Social science as a whole has many branches, each of which is considered a social science (Wikipedia, 2009). 
Social science is, in its broadest sense, the study of society and the manner in which people behave and influence the world around them. Social science tells us about the world beyond our immediate environment and experience, and can help explain how our own society works - from the causes of unemployment or what helps economic growth, to how and why people vote, or what makes people happy (Robert, 1999). It provides vital information for governments and policymakers, local authorities, non-governmental organizations and others.

\section{Disciplines in Social Science}

The specialties, disciplines and subject areas within the family of the social sciences according to William, (1988) include amongst others; Sociology, Social Studies, Economics, Political Science, History, and Geography are considered as Social Sciences. Social science as an academic field of study developed out of the Age of Enlightenment (or the Age of Reason), which flourished through much of the 18th century Europe. The frontline Philosophers whose works remain as compass in the field of the social sciences till date as quoted by Giddens, (2006) are Adam Smith, Voltaire, Jean-Jacques Rousseau, Denis Diderot, Immanuel Kant, David Hume and others. These Philosophers were among some of the giant intellectuals at the time who laid the foundations for the study of social sciences in the Western World. Individuals began to take a more disciplined approach to quantifying their observations of society, and over time similar aspects of a society, such as linguistics and psychology, were separated into unique fields of study, (Giddens, 2006).

\section{Restructuring}

The concept of restructuring has today gained so much attention in Nigeria with the highest level debate of all time particularly since Nigeria became an independent nation on the $1^{\text {st }}$ of October 1960 and 
a Republican State on the $1^{\text {st }}$ October 1963. Restructuring as a concept is basically defined by Hornby (2010) as the act or the process of reorganizing something. It involves a condition of total reorganization of a system, place, thing or an institution for a better performance. The basic structures and institutions of Society, Local Government, Company, State, Nation, Country or even a Continent can be re-organized for a more prospect of specific developmental strides.

Restructuring according to Mathew (2017) means re-defining and re-organizing the present Federal Structure in Nigeria to the system and practice of true federalism as practiced all over the world. He defined it as affects Nigeria as a Nation believing according to him that restructuring Nigeria as a nation will certainly help to move the Nigerian nation forward economically and socially other variables remaining constant. In his analysis, he described the Nigerian government as a centralized form of government from the word go in the history of the Nigerian state. According to Mathew (2017) made the Nigerian state to have a central government popularly called the federal government which is sitted at the centre to be very powerful deciding at every state whatever that happens or that may happen to the Nigerian state. The big powerful central government according to him controls virtually all the affairs of the state government.

Particularly, Mathew (2017) states that today, the federal government controls the amount of resources given to states and the local government, approves the amenities to be put in place by the states as well as the ability of the state to generate power which is grossly against the principle and practice of true Federalism as practiced in civilized environments. Restructuring Nigeria therefore, according to him means to overhaul or to totally change the "status quo" in a manner that the reverse becomes the case here. That is, instead of the federal Government feeding the states with the resources from the states as represented by diagram " $\mathrm{A}$ " below, the 
states should by the principle of restructuring and true federalism as practiced world over begin to determine what goes to the federal government at the centre from the individual states as represented by diagram "B" below
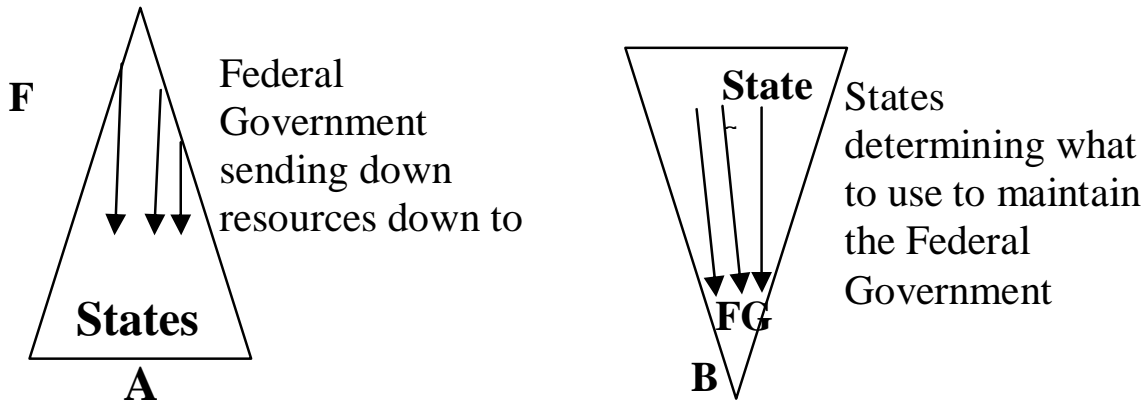

Restructuring according to Mathew (2017) means that the state government should take over the control and the management of all the internal affairs of the country, that is, generate resources and manage it, and only to contribute a percentage of their resources as may be agreed to the maintenance of the centre which is the Federal Government with all of its institutions whose main concern now from the principle of restructuring will limit itself to the management of all international interests of the country. Within the principle of restructuring according to this school of thought, it will now become the responsibility of the Federal government to oversee the Nations foreign policy, the Military and territorial protection, and the economy, while the state government will deal with all internal issues such as electricity generation, building of universities, Construction of roads and security.

\section{Types of Restructuring that Nigeria Need}

The concept of restructuring has attracted attention from scholars, theorists, Social and Political analysts and even policy makers have 
not been left out of the debate on how best the issue of restructuring can best be addressed and what nations whether developed, developing or underdeveloped stand to gain when nations are restructured. Nwabueze (2017) in his article titled: Dissecting the Restructuring that Nigeria Needs published in Daily Post of $28^{\text {th }}$ September 2017, asserts audibly that the clamouring among Nigerians to restructure the nation is not to break-up the nation but that the object is, by reforming the governmental structure and attuning them to the needs and wishes of the Nigerian people, to ensure that the immense diversity of ethnic nationality comprised in the states will continue to co-exist together in peace, progress and unity as citizens of one country. According to him, the clamour for re-structuring is more than glamour for the reform of our governmental structures. This according to him is only the primary focus of the agitation.

Understanding the concept of restructuring according to him is basically the only genuine thing that will certainly help the overall discourse of the subject matter. Reuben (2016) in his part asserts that the concepts of restructuring and federalism seems to have become the most misrepresented words even by those who should understand and work for their actualization in the interest of peace and progress of Nigeria. To some political commentators, according to Reuben (2016), restructuring is an idea whose time has come, if this is true and must be intellectually influenced to be politically enforced for our national good, the basics of the concept of restructuring must be clearly understood and part of this basics is the nature, types and content of restructuring. This according to him is important because there is absolutely nothing that cannot be restructured as far as human existence is concerned. Religion, Education, Transportation, Building, Market, and Security etc. can all be restructured to meet the demand of the present in human environment. Credit therefore to Ikemitang (2017) who has discourse the concept of restructuring from three main perspectives which include: 
a. Political Restructuring,

b. Economic Restructuring,

c. Social Restructuring

Political Restructuring: This has to do with the Political arrangement of the Nigerian Nation, it is changing the political arrangement where the federal government will need to do less than it is currently doing. Political Restructuring must involve substantial devolution of powers from the centre.

Economic Restructuring: Economic Restructuring, is the total overhaul of the economic base of the Nigerian nation. It is total diversification of the economy. It is ending the monolithic nature of the Nigerian economy where the discovery of Crude Oil at Oloibiri killed the existence of Cocoa farm in the West, Oil Palm in the South and the Groundnut explosion in the North. Economic Restructuring means metamorphosing the Nigerian Economy from its today's consumption nature to a largely production economy

Social Restructuring: The concept of social restructuring remains a purely sociological concept which defines the total realignment of the society with urban renewal objectives. This is not just a social reawakening agenda but a strict emphasis on enhanced and progressive social security and social welfare schemes. Social restructuring has to do with purposeful health, housing, unemployment, aged, retired and disabled social security schemes.

Considering the main thrust of this article on Restructuring the Nigerian Nation: The Place of Entrepreneurship Education, attention will wholly rest on "Economic Restructuring and the Nigerian Nation, the way forward. 


\section{What is Economic Restructuring?}

One of the most important aspects of the life of all human societies today is the economic life of the people whether in the most advanced economies or the most underdeveloped nations of the world. Hence, there is always the need for constant movement of the economic structures and institutions of nations of the world from simple to complex, traditional to modern, crude to technological etc.

The concept of economic restructuring may certainly not be popular but it is a regular occurrence in all human socio-economic environments. Economic restructuring according to Sassen, (2006) in her study: Economic Review of Sociology refers to the phenomenon of Western Urban areas shifting from an analog manufacturing to a technology driven production process. It is shifting from a manufacturing to a service sector economic base. It is the economic act of totally shifting from manual labour employment to a technologically driven economy. This process according to her has tremendously helped nearly all nations of the world to move even faster than they ever anticipated and Nigeria cannot afford to be left behind. Looking at the entire process and the need for economic restructuring towards the advancement of nations of the world, manufacturing, insurance, banking, transportation, agriculture, mining, communication etc should be affected by this wave of economic restructuring and quick economic shift to the internet world.

\section{Benefits of Restructuring Nigeria}

To effectively and efficiently consider the benefits accruable to the Nigerian nation from the process and practice of economic restructuring, it is imperative to understand which aspect or types of restructuring are the advocates of the modern day restructuring slogan in Nigeria are mostly concerned with. Are they preaching or advocating political restructuring, economic or social. If their 
argument is an economic restructure, then the views of Swanstrom, (1990) in his article - Urban Policy and Economic Restructuring in Comparative Perspective, Temple University Press will be examined. In his analysis of the benefits of Economic Restructuring to both developed and developing economies remain the most encouraging and inviting and they include:

It is never an academic nor a political fallacy to state unequivocally that a restructured economy today is an improved and a purely progressive economy. It is a production and service driven economy. A restructured economy is a scientific and technology based economy. The Nigerian economy today to say the least need the most radical type of economic restructuring if the economy must meet up with today's global economic demand. Examining the obvious benefits of restructuring as observed by Odumakin (2017) in his article of 19/09/2017 published in Vanguard online titled: "Ten Reasons to Restructure Nigeria", he affirmed that a number of unquantifiable benefits are hidden in sincere, efficient, effective, responsive and functional restructuring of the Nigerian state and according to him, the Nigerian economy cannot be divorced from the beauty of restructuring. A restructured economy in the Nigerian nation is an economy according to Odunmakin, where every area, region or zone of the country will be able to devote more thinking time, conceptualization, research, exploration and analysis to its mineral and agricultural resources. Generally speaking, Economic Restructuring is a view to developing an economic value-chair and platform which is the first serious step towards the development of a manufacturing capacity across the country-which will eventually result in an economic and infrastructural development of the Nigerian state.

Odunmakin (2017) further asserts that when governments and private investors in every part of the country, are challenged to look for sources of Wealth - Creation primarily within their own region, 
and to work with international investors to transform these natural endowments within their local environment into real economic empowerment for millions of their people, then we will certainly know that a sincere economic restructuring is a national journey worth undertaking without looking book (Odunmakin, 2017).

\section{Social Science Education the Principle of Effective and Efficient Restructuring}

Social science Education being the study of society and the manner in which people behave and influence the world around us cannot be divorced from the issue of restructuring and the several other ways through which man intend to constantly organize and reorganize his immediate Socio Economic, Political and Cultural environment. According to Economic and Social Research Council (2018) Social science tells us about the world beyond our immediate experience, and can help explain how our own society works from the causes of unemployment or what helps economic growth, to how and why people vote, or what makes people happy including the nature of their surrounding and their entire State of affairs. Social science Education by providing relevant information and knowledge, skills and attitudes, the study of Social Science prepares students to grow up as active, responsible, and reflective members of society with the comprehensive of how their Society is organized. It also teaches them to address societal and global concerns using knowledge, skills, competence and abilities gained in Social Science Education classrooms and outside classrooms instructional hours such as during field experience.

Social Science is a branch of study which deals with Human Beings - their behaviour, growth and development, relationships, resources they use and the various institutions they require to function and carry on their life smoothly. For example family, school, workplace, government, judiciary, recreation clubs, etc. All these 
aspects of life are inter-related and interdependent on one another. So whether one wants to become a doctor or an engineer or a chartered accountant, an artist or a teacher, we all have to live in a society, interact with individuals belonging to different cultural and socioeconomic backgrounds, adapt to various situations and circumstances, and also adhere to certain societal norms in order to lead a peaceful and productive life. This knowledge of Social Science enables the students to understand how the world and different societies have evolved, the important events that have occurred in the past, enduring ideas and helps to develop critical thinking abilities that will position them as better teachers, administrators, leaders and policy makers putting into the right perspective issues and policies as it affects restructuring and reorganizing their environment for better sustainable development particularly in this era of entrepreneurship and Economic development.

\section{Entrepreneurship and Economic Restructuring in Nigeria}

It is indeed pertinent here to state the obvious that there is significant relationship between the concepts and practice of Entrepreneurship Education and Economic Restructuring in Nigeria. Economic restructuring summarily means the outright shift of the economic base of any nation from where it is to where it ought to be, Nigeria inclusive particularly the shift from a consumption economy to a production and service based economy. And this is practically dependent on the nature of education curriculum operational within the nation in question. Until the educational system in Nigeria is made a full practice based education system, the sectors of the nation will practically remain static with a deep void waiting to be filled and it is only a functional and productive Entrepreneurship Education that is well taught to the students and to the Nigerian people that is capable of filling this gap that exist in Nigeria between Education and Development in Nigeria. 


\section{What is Entrepreneurship Education?}

The concepts of Entrepreneurship and Entrepreneurship Education is not novel in the world of education and development but the demand of modern day Nigeria occasioned by huge unemployment and under employment crises has made the twin concepts of Entrepreneurship and Entrepreneurship Education to gain so much popularity than it ought to in an ideal society.

The twin concepts of Entrepreneurship and Entrepreneurship Education took their root from the word "entrepreneur" which originally comes from the combination of two Latin words "entre" meaning to swim out, and "prendes", to grasp, understand or capture. This is according to the popular Irish Economist, Jean-Baptiste in 1800 who combined the two words to read "entrepreneur" and popularized it, (Masschallenge, 2012).

The word entrepreneur, according to Louge (2008) refers to the factor of production that coordinates and organizes other factors of production (Land, labour and capital) in other to produce goods and services to earn maximum profit. The entrepreneur, as Louge (2008) further explained bears the risk and takes major decisions of the business with the major focus on profit maximization at all fronts. The entrepreneur is one who risks his capital in setting up a business with the aim of obtaining maximum profit. Koontz and Weihrich (1998) further explained that entrepreneurs are people with the ability to see an opportunity, obtained the necessary capital, labour and other inputs, and also know how to put together an operation successfully for proceeds, and with the willingness to take personal risk for success. Summarily, an entrepreneur is one who starts his own business with the mind of making maximum benefits.

The urge to educate people on the need to embrace the concept of entrepreneur and its principle of creativity, production, development and improvement of life and human environment is primarily what gave birth to the concept of Entrepreneurship 
education in the school system (Iwegbu, 2013). Entrepreneurship Education therefore seeks to provide students with the requisite knowledge, skills and motivation to encourage entrepreneurial success in a variety of settings. Variations of Entrepreneurship education are offered at all levels of schooling from primary, secondary schools through graduate university programmes to achieve the original intention of the initiative which is to develop skills that will improve life and reduce unemployment (Iwegbu, 2013).

Entrepreneurship Education according to Uyamasi (2011) offers students unlimited opportunities by helping them anticipate and respond to change in the economic environment of their nation. In his own view, Nwokolo (1997) opined that Entrepreneurship Education is an aspect of education that is geared towards developing in students, skills, ideas and managerial abilities necessary for self-reliance. Entrepreneurship Education is a programme of human capital resource development. The main thrust of Entrepreneurship Education according to Nzetibe (1996) is on developing skills to create labour efficiency for self-reliance and maximum generation of capital for human and national development. Unequivocally speaking therefore, if sustainable progress must be made in the pursuit of national economic restructuring in Nigeria, adequately financed Entrepreneurship Education must be given its pride of place.

\section{The Role of Entrepreneurship Education in the Economic Restructuring of Nigeria}

Entrepreneurship Education which according to Iwegbu (2013) is an educational programme designed to instil in students the basic knowledge of entrepreneurial skills, knowledge, abilities and competence for self-reliance and sustainability geared towards personal and national development. This form of education as Uyamasi (2011) emphasized, if adequately financed and taught to 
students will remain key driver of the Nigerian economy, therefore, if the importance of Entrepreneurship Educations and its role on Economic Restructuring as identified by I.N.D.A.A Trust (2007) and listed below must be taken seriously as they are, it means restructuring the Nigerian economy cannot in anyway do without Entrepreneurship Education (Uwaifo (2018) reporting Adekunle and Kayode (2014)).

\section{Objectives of Entrepreneurship Education to Include}

1. Positive attitude, high aptitude for rational critical thinking and timely decision making.

2. Clear vision, generation of progressive ideals, drive and passion for success

3. Ability to convert vision to concrete reality

4. Creativity, innovativeness, courageousness and self confidence

5. Ability to assure reasonable tasks

6. Material ingenuity, resourcefulness, patience and/or opportunities insight

7. Confidence and good judgement, which involves taking decisions and making choices

8. Produce, which means due care in the management of resources especially finance

9. Willingness to learn and develop a disposition to pick - up knowledge and use it.

10. Hard work an indispensible ingredient of success in business and other sectors.

\section{Importance of Entrepreneurship Education}

a. Entrepreneurship Education is a key driver to any economy, whether already developed, developing or underdeveloped. 
b. Wealth and a high majority of jobs are created by small businesses started by entrepreneurially minded individuals, many of whom go on to create big businesses conglomerates.

c. People exposed to Entrepreneurship abilities and competence, frequently express that they have more opportunity to exercise creative freedoms, higher self esteem, and an overall greater sense of control over their own lives.

d. As a result, many experienced business people, political leaders, economists, and educators believe that fostering a robust entrepreneurial culture in nations will maximize individual and collective economic and social success on a local, national and global scale.

e. Entrepreneurship Education develops in nation's principles and policy initiatives that shift a nation from the stagnated consumption economy to a progressive production economy that catapults development in all ramifications.

Considering the above, the role of Entrepreneurship education in economic restructuring of Nigeria is basically to create skills, knowledge, abilities and competence that will shift the Nigeria economy from its monolithic and consuming nature of today to a well diversified and competitively productive economy ready to take its pride of place in the committee of world Most Productive Nations.

\section{Challenges of Economic Restructuring}

The thought of restructuring in Nigeria particularly, the call for economic restructuring is to say the least the best for Nigeria in the face of global economic meltdown and frustrating unemployment that has almost plummeted the Nigerian economic life irredeemably. But one thing is sure; the pending challenges can be whittled down into the following subheads:

a. Economic 

b. Social
c. Political
d. Environmental
e. Cultural

It is truly saddening to note that these factors may remain strong clogs on the wheel of Nigerian economic progress if these critical challenges on this well intentioned marriage between Entrepreneurship Education and Economic restructuring are not put totally under check.

\section{Conclusion}

Entrepreneurs play a very important role in nearly all leading economies all over the world just like Singapore that was aided by their policy on economic restructuring that was implemented without prejudice, which immensely aided their productivity level, improvements and innovative breakthroughs. Today, Singapore economy is in the fastest economic transition of all times according to I.N.D.A.A Trust (2007) and if Nigeria must be better for Nigerians and she aim to become more productive, innovative and developmentally minded, the people must be willing and more committed at all fronts to see Nigeria advanced more than just the clamour for restructuring. It is very obvious today that the way to go for the nation of Nigeria to get out of the economic wood is functional Entrepreneurship Education. This is practically because entrepreneurs play very important roles in the economic restructuring of any nation whether advanced or advancing. Indeed, glaring evidence abounds all over the world that Entrepreneurs are game changers when it come to the economic growth of any nation in the world.

If this new economic transformation marriage of Entrepreneurship Education with Economic Restructuring in Nigeria must work, all hands must be on deck. But the following salient points are sacrosanct: 
a. Legislation on making Entrepreneurship Education compulsory from the lowest level of schooling were the love for creativity should be inculcated into the pupils/students to the graduate level of education in Nigeria for the benefit of mastery and practicability of the concept and contents of Entrepreneurship Education.

b. Adequate learning environment must be provided with well equipped rooms, halls and laboratories.

c. There must be adequate training of the specialist teachers in these areas.

d. Remuneration and motivation of the teachers and school administrators are important.

e. Efforts should be made to create ready markets for the products of this initiative.

Chuks Justus Iwegbu

Department Of Social Studies

College Of Education, Agbor

Delta State

$\&$

Emmanuel C. Uwaifo

Department of Economics

College of Education, Agbor

Delta State

\section{References}

Adekunle O. \& Kayode, D.J (2014) Entrepreneurship Education in Nigerian Universities Outputs and their Employability in the Labour Markets in South - South Nigeria, American Journal of Educational Research 1244 - 1245

Giddens, A (2006). Sociology: Meaning. Concepts, Theories and Practice. Oxford, UK: Polity.p. 714. ISBN 0-7456-3379-X . 
Hornby A.S (2010), Oxford Advanced Learners Dictionary of current English ( $6^{\text {th }}$ Edition). Oxford; Oxford University Press

Ikemitang, S (2017) Nigeria: Political Restructuring or Economic Restructuring, retrieved 10/012018. In punchng.com

Iwegbu C.J (2013) Winning the War on Unemployment: The Role of Entrepreneurship Education and Skill Acquisition in ASSFN Journal of Growth and Development, 3 (1)

I.N.D.A.A Trust (2007) Youths Entrepreneurship Education: An Action Guide. Retrieved 14/01/2018. In India Trust.org

Koontz, H and Weihrich, H (1998), Essentials of Management. $5^{\text {th }}$ Edition, New Delhi: Tata McGraw - Hill Publishing Company Limited

Louge, O.A (2008), Essential Commerce for Senior Secondary Schools, Ibafo, Tonad Publishers

Masschallenge, M.C (2012) The Etymology of the Entrepreneur: Boston, Masschallenge Publications Incorporated

Mordi, A.A \& Jike, V.T (2005) Introduction to Philosophy of the Social Sciences, Abraka, Faculty of the Social Sciences, Delta State University, Abraka, Nigeria.

Nwokolo A. (1997) Youths Entrepreneurship Education: A Panacea for Youth Unemployment in Uyamasi, C.C and Ofuasia J.N Essentials of Economic Activities of Man for Tertiary Institutions; Agbor, Suntex Productions

Robert A (1999). The Cambridge Dictionary of Philosophy (Second ed.). Cambridge: Cambridge University Press. p. 704.

Odumakin Y. (2017) Restructuring is the Only Option for Nigeria's Survival, in www.guardian.ug.com retrieved 16/04/2020

Reuben A. (2016) Restructuring Nigeria to Save it in 247ureport.com retrieved 16/04/2020

Uwaifo, C. E (2018) Entrepreneurship Education: Tool for Human Capital Development and 
Entrepreneurship in Nigeria in Journal of Arts and Social Sciences, College of Education Agbor, Vol 1, No 12

Uyamasi, C.C\&Ofuasia J.N (2011) Essentials of Economic Activities of Man for Tertiary Institutions; Agbor, Suntex Productions

William, H. (1988) Key Contemporary Thinkers, Polity Press (Second Edition 2009), ISBN 978-0-7456- 4328-1 p.19

Wikipedia, (2009) Principle and Practice of Social Sciences 25/08/2018 in https://en.m.wikipedia.org > wiki > School, retrieved 06/09/2020

Nzelibe, C.G.O. (1996): Entrepreneurship and Management of Small Scale Business: Enugu: Optimal Publishers. 